\title{
Aplikasi Multi Criteria Decision Making Dalam Penerimaan Beasiswa Kepada Dosen Studi Lanjut STMIK Balikpapan Menggunakan Metode SAW
}

\author{
Muslimin B*1, Sumardi ${ }^{2}$ \\ Program Studi Teknik Informatika, STMIK Balikpapan, Kalimantan Timur, Indonesia \\ e-mail: *11 muslimin@stmikbpn.ac.id, ${ }^{2}$ sumardi@stmikbpn.ac.id
}

\begin{abstract}
Abstrak
Peminat dan jumlah pendaftaran mahasiswa baru STMIK Balikpapan setiap tahun semakin bertambah. Keseimbangan rasio dosen dengan mahasiswa merupakan salah satu komponen terpenting dalam meningkatkan mutu dan proses belajar mengajar suatu perguruan tinggi. Menghindari kekurangan jumlah dosen pengampu matakuliah dapat diwujudkan dengan memberikan program beasiswa kepada alumni dan asisten dosen. Penelitian ini bertujuan membangun suatu aplikasi multi criteria decision making yang dapat membantu Kepala HRD dalam proses penerimaan beasiswa kepada dosen studi lanjut secara efektif dan lebih akurat.

Aplikasi multi criteria decision making yang dikembangkan dalam penelitian ini menggunakan metode SAW. Implementasi metode SAW meliputi proses evaluasi bobot kriteria, evaluasi bobot alternatif, proses matrik, hasil preferensi pengambilan keputusan, sehingga menghasilkan bobot dan ranking setiap alternatif calon penerima beasiswa.

Hasil evaluasi aplikasi multi criteria decision making dalam penelitian diharapkan dapat menghasilkan pemodelan dengan tingkat akurasi yang tinggi. Hasil analisa yang dilakukan dapat memberikan rekomendasi alternatif calon penerima beasiswa kepada dosen studi lanjut di lingkungan STMIK Balikpapan.
\end{abstract}

Kata kunci-Beasiswa, Metode SAW, Multi Criteria Decision Making

\section{Abstract}

Interests and number of STMIK Balikpapan new student enrollments are increasing every year. The balance of the ratio of lecturers to students is one of the most important components in improving the quality and teaching and learning process of a university. Avoiding shortages in the number of lecturers can be realized by providing scholarship programs to alumni and teaching assistants. This study aims to build a multi criteria decision making application that can assist the Head of HRD in the process of receiving scholarships to advanced and effective study lecturers.

The multi criteria decision making application developed in this study uses the SAW method. The implementation of the SAW method includes the process of evaluating the weighting of criteria, evaluating alternative weights, the matrix process, the results of decision making preferences, resulting in the weighting and ranking of each alternative candidate for the scholarship recipient.

The results of the evaluation of multi-criteria application decision making in the study are expected to produce modeling with a high degree of accuracy. The results of the analysis carried out can provide alternative recommendations for prospective scholarship recipients to advanced study lecturers in STMIK Balikpapan.

Keywords - Scholarship, SAW Method, Multi Criteria Decision Making 


\section{PENDAHULUAN}

STMIK Balikpapan merupakan salah satu perguruan tinggi swasta yang berada di kota Salikpapan, Kalimantan Timur. Perkembangan dan kualitas instansi pendidikan suatu perguruan tinggi dapat diwujudkan dengan peningkatan mutu dosen, jumlah penelitian dosen, pengabdian masyarakat serta terpenuhi jumlah rasio dosen dengan mahasiswa. Salah satu kendala instansi perguruan tinggi di wilayah Kalimantan Timur disebabkan karena tidak seimbangannya antara rasio dosen dengan mahasiswa, serta cenderung susah mendapatkan dosen dengan kualifikasi pendidikan yang linier antara pendidikan Strata I dengan Strata II, khususnya bidang informatika dan komputer.

Dalam memenuhi jumlah rasio dosen, STMIK Balikpapan setiap tahun melakukan proses seleksi penerimaan beasiswa kepada dosen studi lanjut program Strata II. Beasiswa adalah suatu upaya penghargaan dan bantuan finansial kepada mahasiswa yang dapat mendorong kemajuan studi pada suatu perguruan tinggi[1]. Dana bantuan beasiswa umumnya diberikan kepada siswa, mahasiswa, calon dosen yang bersumber dari instansi pemerintah atau pihak swasta. Calon penerima beasiswa yang akan diusulkan dalam melanjutkan studi Strata II merupakan alumni dan telah mengabdi sebagai asisten dosen di lingkungan kampus STMIK Balikpapan. Pemilihan beberapa asisten dosen dan alumni sebagai calon kandidat penerima beasiswa akan dievaluasi berdasarkan track record bidang keahliannya masing-masing.

Seleksi penerimaan beasiswa dosen studi lanjut di lingkungan STMIK Balikpapan masih bersifat manual, sehingga dibutuhkan sebuah aplikasi yang interaktif, cepat dan tepat dalam pengambilan keputusan. Implementasi aplikasi dan proses evaluasi pengambilan keputusan diharapkan memberikan sebuah output yang lebih akurat dan tepat sasaran. Pemilihan beasiswa dengan menggunakan mesin learning dapat melakukan prediksi calon penerima beasiswa yang layak dengan tingkat akurasi tinggi[2]. Aplikasi pengambilan keputusan yang akan dibangun dapat menerapkan salah satu pemodelan multi criteria decision making.

Multi criteria decision making merupakan teori yang dapat mengintegrasikan antara logika penalaran, matematika, ilmu komputer, riset operasi, ilmu manajemen untuk menyelesaikan masalah dari beberapa attribut dalam dunia nyata[3]. Penalaran pengetahuan menggunakan multi criteria decision making dapat menyelesaikan permasalahan yang bersifat kuantitatif dan kualitatif[4]. Proses learning dan knowledge dengan menerapkan salah satu metode dalam pemodelan multi criteria decision making dapat menyelesaikan pengambilan keputusan[5]. Multi criteria decision making terdiri dari beberapa metode yang dapat di terapkan, diantaranya metode weighted product(WP), PROMETHEE, Topsis, analytic hierarchy process $(A H P)$, simple additive weighting $(S A W)$. Berdasarkan hasil evaluasi yang dilakukan multi criteria decision making dapat memberikan identifikasi hasil pengambilan keputusan yang optimal[6]. Penerapan pemodelan aplikasi menggunakan metode SAW dapat mendukung proses analisa dan penentuan penerimaan beasiswa kepada dosen studi lanjut STMIK Balikpapan.

Metode SAW merupakan metode penjumlahan bobot yang sederhana dan menghasilkan nilai dengan akurasi cukup tinggi[6]. Kelebihan metode SAW adalah dapat mengidentifikasi analisis sensitivitas sehingga dapat memecahkan permasalahan dengan kemampuan grafis komputer, mengevaluasi bobot kriteria dan alternatif dan menghasilkan bobot ranking[7]. Tahapan utama multi criteria decision making menggunakan metode SAW meliputi manajemen kriteria dan alternatif, evaluasi kriteria dan alternatif. Manajemen kriteria merupakan proses evaluasi kriteria-kriteria dibutuhkan dalam penerimaan beasiswa, manajemen alternatif merupakan calon candidat (asisten dosen dan alumni) sebagai penerima beasiswa, evaluasi kriteria merupakan memberian nilai preferensi kriteria dengan skala pembobotan, evaluasi alternatif merupakan pemberian nilai preferensi bobot alternatif berdasarkan kriteria, sehingga menghasilkan bobot kriteria dan alternatif. Akumulasi bobot tersebut menghasilkan ranking individu setiap calon penerima beasiswa yang dapat melanjutkan studi ke jenjang Strata II.

Penelitian ini diharapkan dapat membantu Kepala HRD dalam menyelesaikan masalah analisa dan pemilihan penerimaan beasiswa kepada dosen studi lanjut di lingkungan STMIK Balikpapan secara akurat.

JSIKTI Vol. 2, No. 3, June 2020 : $31-40$ 


\section{METODE PENELITIAN}

\subsection{Sistem Pendukung Keputusan}

Sistem pendukung keputusan adalah suatu sistem yang dapat digunakan untuk mendukung para pengambil keputusan manajerial untuk memperluas kemampuan mereka dalam situasi keputusan semi terstruktur[8]. Sistem pendukung keputusan merupakan alat bagi para pengambil keputusan, namun tidak untuk menggantikan peran penilaian mereka. Sistem pendukung keputusan didefinisikan oleh Turban et al. (2005) sebagai sebuah sistem yang digunakan untuk mendukung para pengambil keputusan menejerial untuk memperluas kemampuan mereka dalam situasi keputusan semi terstruktur. Sistem pendukung keputusan merupakan alat bagi para pengambil keputusan, namun tidak untuk menggantikan peran penilaian mereka. Definisi (Gorry \& Scott Morton 1971) dalam (E Turban et al. 2005) menyatakan bahwa sistem pendukung keputusan adalah sebagai sistem berbasis komputer interaktif yang membantu para pengambil keputusan untuk menggunakan data dan berbagai model untuk memecahkan masalah-masalah tidak terstruktur.

Menurut Little (1970) dalam Turban et al. (2005) mendefinisikan sistem pendukung keputusan sebagai sekumpulan prosedur berbasis model untuk data pemprosesan dan penilaian untuk membantu para menejer mengambil keputusan. Dia menyatakan bahwa untuk menjadi sukses, sistem tersebut haruslah sederhana, cepat, mudah dikontrol, adaptif, lengkap dengan isu-isu penting, dan mudah berkomunikasi. Sedangkan Moore \& M. G. (1980) dalam Turban et al. (2005) mendefinisikan sistem pendukung keputusan sebagai sistem yang dapat diperluas untuk mampu mendukung analisis ad hoc data dan pemodelan keputusan, berorientasi terhadap perencanaan masa depan, dan digunakan pada interval yang tidak regular dan tak terencana.

Definisi sistem pendukung keputusan menurut (Turban \& Bonczek 2005) menyatakan sistem pendukung keputusan sebagai sistem berbasis komputer yang terdiri dari tiga komponen yang saling berinteraksi: sistem bahasa (mekanisme untuk memberikan komunikasi antar pengguna dan komponen sistem pendukung keputusan yang lain). Sistem pengetahuan (repositori pengetahuan dominan masalah yang ada dalam sistem pendukung keputusan sebagai data atau sebagai prosedur) dan sistem pemrosesan masalah (hubungan antar komponen lainnya terdiri dari satu atau lebih kapasistas manipulasi masalah umum yang diperlukan untuk pengambilan keputusan). Konsep-konsep yang diberikan oleh definisi tersebut sangat penting untuk memahami hubungan sistem pendukung keputusan dengan pengetahuan. Sedangkan keen dalam (E Turban et al., 2005) mendefinisikan sistem pendukung keputusan sebagai produk dari proses perkembangan, dimana pengguna sistem pendukung keputusan, pembangun sistem pendukung keputusan, dan sistem pendukung keputusan itu sendiri mampu mempengaruhi satu sama lain, sehingga terjadi evolusi sistem dan pola penggunaan.

\section{2 Multi Criteria Decision Making}

Multi criteria decision making adalah suatu metode investigasi yang dapat menyelesaikan pengambilan keputusan dengan permasalahan kriteria yang saling bertentangan[9]. Penerapan metode multi criteria decision making dapat menghasilkan interaksi, sinergi kriteria yang digunakan, serta mengindari terjadinya redundansi data. Beberapa pemodelan yang dapat diselesaikan menggunakan multi criteria decision making, diantaranya metode SAW, weighted product, PROMETHEE, AHP[10], metode Fuzzy, AHP, Topsis[4].

MCDM adalah suatu metode pengambilan keputusan untuk menetapkan alternatif terbaik dari sejumlah alternatif berdasarkan beberapa kriteria tertentu. Kriteria biasanya berupa ukuranukuran atau aturan-aturan yang digunakan dalam pengambilan sebuah keputusan. Secara umum dapat dikatakan bahwa MCDM menyeleksi alternatif terbaik dari sejumlah alternatif (Saragih, 2012). MCDM juga merupakan teori yang membahas mengenai proses pengambilan keputusan 
dengan mempertimbangkan banyaknya kriteria. Teori ini dapat dibagi menjadi dua jenis berdasarkan sifat dari alternatif yaitu ;

1. Multi attribute decision making (MADM), pada teori ini jumlah alternatif telah diketahui sebelum proses penambil keputusan dilakukan.

2. Multi objective decision making (MODM), pada teori ini jumlah alternatif dianggap tidak terbatas dan dirancang menggunakan data kontinu dengan model matematika.

MADM merupakan teori pengambilan keputusan yang mempertimbangkan sekumpulan alternatif pilihan yang telah diketahui sebelumnya terhadap kriteria yang banyak. Permasalahan MADM dapat diformulasikan sebagai berikut, misalkan ada sejumlah $\mathrm{M}$ kriteria dan $\mathrm{N}$ alternatif, dimana $C_{1}, \ldots, C_{n}$ adalah kriteria dan $A_{1}, \ldots, A_{n}$ adalah alternatif maka akan dipilih sebuah atau sekumpulan alternatif yang memenuhi kriteria semaksimal mungkin.

Pada penelitian ini digunakan MADM karena solusi yang akan dibangun merupakan seleksi terhadap beberapa alternatif dalam jumlah terbatas, proses dalam MADM dilakukan melalui 3 tahapan, diantaranya;

1. Tahap pertama dilakukan penyusunan komponen-komponen situasi, analisis dan sintesis informasi. Pada tahap ini dibentuk tabel taksiran yang berisi identitas alternatif, spesifikasi tujuan, kriteria dan attribute. Salah satu cara untuk menspesifikasikan tujuan situasi $\left|O_{t}=1, \ldots, t\right|$ adalah mendaftar konsekuensi yang mungkin dari alternatif yang telah teridentifikasi $\left|\mathrm{A}_{i}=1, \ldots, n\right|$. Selain itu juga disusun attribute-attribute yang digunakan $\mid \alpha_{k}$ $=1, \ldots, m$

2. Tahap analisis I dilakukan dengan mendatang taksiran dari besaran potensial, kemungkinan-kemungkinan ketidakpastian yang berhubungan dengan dampak-dampak yang mungkin pada setiap alternatif.

3. Tahap Analisis II dilakukan dengan pemilihan dari preferensi pengambilan keputusan untuk setiap nilai dan ketidak pedulian terhadap resiko yang timbul.

Secara umum model multi attribute decision making didefinisikan sebagai berikut, misalkan $A$ $=\left\{\alpha_{i} \mid i=1, \ldots, n\right\}$ adalah himpunan alternatif-alternatif keputusan dan $C=\left\{C_{j} \mid J=1, \ldots, m\right\}$ adalah himpunan tujuan yang diharapkan, maka ditentukan alternatif $X^{0}$ yang memiliki derajat harapan tertinggi terhadap tujuan-tujuan yang relevan $\mathrm{C}_{\mathrm{j}}$. Pada identifikasi sub kriteria dan kriteria, (Chen \& Cheng, 2005) menyatakan untuk menggabungkan nilai bobot sub kriteria sebagai faktor pembentuk nilai bobot kriteria dengan persamaan (3.40),

$X_{\mathrm{i}}=\frac{\sum_{k=1}^{j} X_{i j}}{n X_{i j}}$

Dimana,

$$
\begin{aligned}
& X_{i}=\text { Kriteria ke } i \\
& X_{i j}=\text { Bobot sub kriteria ke } i j \\
& \mathrm{n}=\text { Banyaknya sub kriteria }
\end{aligned}
$$

Pendekatan multi stage multi attributee group decision making, hampir semua kasus pengumpulan attribute kriteria dilakukan pada tahap yang sama dan tidak mempertimbangkan waktu pengambilan data pada matrik keputusan. Secara umum, pengambilan data pada tahap / waktu yang berbeda memiliki tingkat kepentingan yang berbeda, sehingga harus diberikan bobot yang berbeda. Pendekatan Multi-stage Multi Attributee Group Decision Making (MSMAGDM) merupakan metode yang dipergunakan untuk melakukan pengambilan keputusan dengan mempertimbangkan bobot waktu pengambilan data attribute kriteria. Metode ini berguna pada masalah multi tahap pengambilan keputusan seperti : keputusan investasi, diagnosis medis, penilaian personil dinamis, sistem evaluasi kinerja dan performance. Keterbaharuan penelitian ini adalah penentuan bobot dengan poison distribution, menggunakan hybrid weight agregation (HWA) operator dan time weighted averaging (TWA) untuk memadukan penilaian pembuat keputusan individu dan opini individu dan berkelompok.

MADM merupakan teori pengambilan keputusan yang mempertimbangkan sekumpulan alternatif pilihan yang telah diketahui sebelumnya terhadap kriteria dengan jumlah yang

JSIKTI Vol. 2, No. 3, June 2020: $31-40$ 
banyak. Permasalahan MADM dapat di formulasikan sebagai berikut, misalkan ada sejumlah $\mathrm{M}$ kriteria dan $\mathrm{N}$ alternatif, dimana $\mathrm{C}_{1}, \ldots, \mathrm{C}_{\mathrm{n}}$ adalah kriteria dan $\mathrm{A}_{1}, \ldots, \mathrm{A}_{\mathrm{n}}$ adalah alternatif maka akan dipilih sebuah atau sekumpulan alternatif yang memenuhi kriteria semaksimal mungkin.

Merupakan tiga langkah umum yang dilakukan dalam menerapkan metode MADM dalam pengambilan keputusan, yaitu :

a. Menentukan kriteria dan alternatif.

b. Menentukan ukuran numerik kepentingan kriteria dan nilai alternatif terhadap kriteria.

c. Memproses nilai-nilai numerik tersebut untuk menentukan ranking setiap alternatif.

Tabel 1 Matrik keputusan

\begin{tabular}{|c|l|l|l|l|l|}
\hline \multicolumn{7}{|c|}{ Kriteria } \\
\hline Alternatif & $\mathrm{C}_{1}$ & $\mathrm{C}_{2}$ & $\mathrm{C}_{3}$ & $\ldots$ & $\mathrm{C}_{\mathrm{n}}$ \\
\cline { 2 - 6 } & $\mathrm{W}_{1}$ & $\mathrm{~W}_{2}$ & $\mathrm{~W}_{3}$ & $\ldots$ & $\mathrm{W}_{\mathrm{N}}$ \\
\hline $\mathrm{A}_{1}$ & $\mathrm{a}_{11}$ & $\mathrm{a}_{12}$ & $\mathrm{a}_{12}$ & & $\mathrm{a}_{1 \mathrm{~N}}$ \\
\hline $\mathrm{A}_{2}$ & $\mathrm{a}_{21}$ & $\mathrm{a}_{22}$ & $\mathrm{a}_{23}$ & & $\mathrm{a}_{2 \mathrm{~N}}$ \\
\hline $\mathrm{A}_{3}$ & $\mathrm{a}_{31}$ & $\mathrm{a}_{32}$ & $\mathrm{a}_{33}$ & & $\mathrm{a}_{3 \mathrm{~N}}$ \\
\hline$\ldots$ & $\ldots$ & $\ldots$ & $\ldots$ & $\ldots$ & $\ldots$ \\
\hline $\mathrm{A}_{\mathrm{m}}$ & $\mathrm{a}_{\mathrm{M} 1}$ & $\mathrm{a}_{\mathrm{M} 2}$ & $\mathrm{a}_{\mathrm{M} 3}$ & $\ldots$ & $\mathrm{a}_{\mathrm{MN}}$ \\
\hline
\end{tabular}

\section{3 Metode $S A W$}

Metode SAW merupakan salah satu metode preferensi pengetahuan dalam multi criteria decision making. Metode $S A W$ adalah metode yang sederhana yang dapat memvalidasi bobot dengan akurat yang tinggi dengam mempertimbangkan kriteria yang digunakan[10]. Tahapan utama proses evaluasi metode SAW[7], meliputi:

1. Melakukan proses normalisasi matriks keputusan, Normalisasi matriks dapat dilihat pada persamaan 1 .

$$
r_{i j}=\left\{\begin{array}{l}
\frac{x_{i j}}{\max x_{i j}} \\
\frac{\min }{x_{i j}}
\end{array}\right.
$$

2. Dimana $\mathrm{r}_{\mathrm{ij}}$ merupakan rating kinerja ternormalisasi dari alternatif, $\mathrm{x}_{\mathrm{ij}}$ nilai attribut yang dimiliki dari setiap kriteria, $\max _{\mathrm{ij}}$ nilai terbesar dari setiap kriteria, $\min _{\mathrm{ij}}$ nilai terkecil dari kriteria.

3. Menentukan nilai preferensi setiap alternatif.

Penentuan nilai preferensi dapat dilihat pada persamaan 2 .

$$
v_{i}=\sum_{j=1}^{\mathrm{D}} w_{j} \mathrm{r}_{\mathrm{ij}}
$$

Dimana $v_{i}$ ranking untuk setiap alternatif, $\mathrm{w}_{\mathrm{j}}$ nilai bobot kriteria, $\mathrm{r}_{\mathrm{ij}}$ nilai rangking ternormalisasi.

\section{4 Beasiswa}

Beasiswa merupakan upaya penghargaan dan bantuan finasial kepada mahasiswa yang dapat mendorong kemajuan studi pada suatu perguruan tinggi[1]. Pemberian beasiswa biasanya di danai oleh pemerintah atau pihak swasta bersifat komersil yang mengalokasikan dana keuangan yang mendukung kegiatan pendidikan. Adapun kriteria dari penerima beasiswa adalah Pengajaran, Penelitian, Pengabdian dan Pendidikan 


\section{5 Arsitektur Sistem}

Arsitektur sistem merupakan gambaran umum tentang proses pemodelan sistem dalam proses evaluasi penerimaan beaisiswa untuk dosen studi lanjut di lingkungan STMIK Balikpapan. Alur kerja arsitektur sistem tersebut, maka fungsi setiap proses tersebut meliputi:

1. Data internal.

Merupakan data alumni dan asisten dosen STMIK Balikpapan yang akan diseleksi sebagai calon penerima beasiswa yang akan melanjutkan studi.

2. Basisdata sistem pendukung keputusan.

Merupakan data kriteria, sub kriteria dan alternatif (calon penerima beaisiswa) yang akan diproses dalam aplikasi multi criteria decision making.

3. Basis model sistem pendukung keputusan.

Merupakan proses evaluasi model dengan menggunakan metode SAW dalam proses penalaran pengetahuan dalam aplikasi.

4. Manajemen data

Merupakan proses singkronisasi kebutuhan antar data-data yang digunakan.

5. Manajemen model

Merupakan kemampuan dan nilai efektifitas yang telah diproses dan dihasilkan oleh pemodelan menggunakan metode SAW.

6. User interface

User interface merupakan antarmuka atau tampilan aplikasi multi criteria decision making. User interface merupakan tampilan aplikasi dimana pengguna(admin dan kepala HRD) melakukan proses interaksi dengan aplikasi yang telah di rancang. Alur kerja dan proses arsitektur sistem dapat dilihat pada Gambar 1.

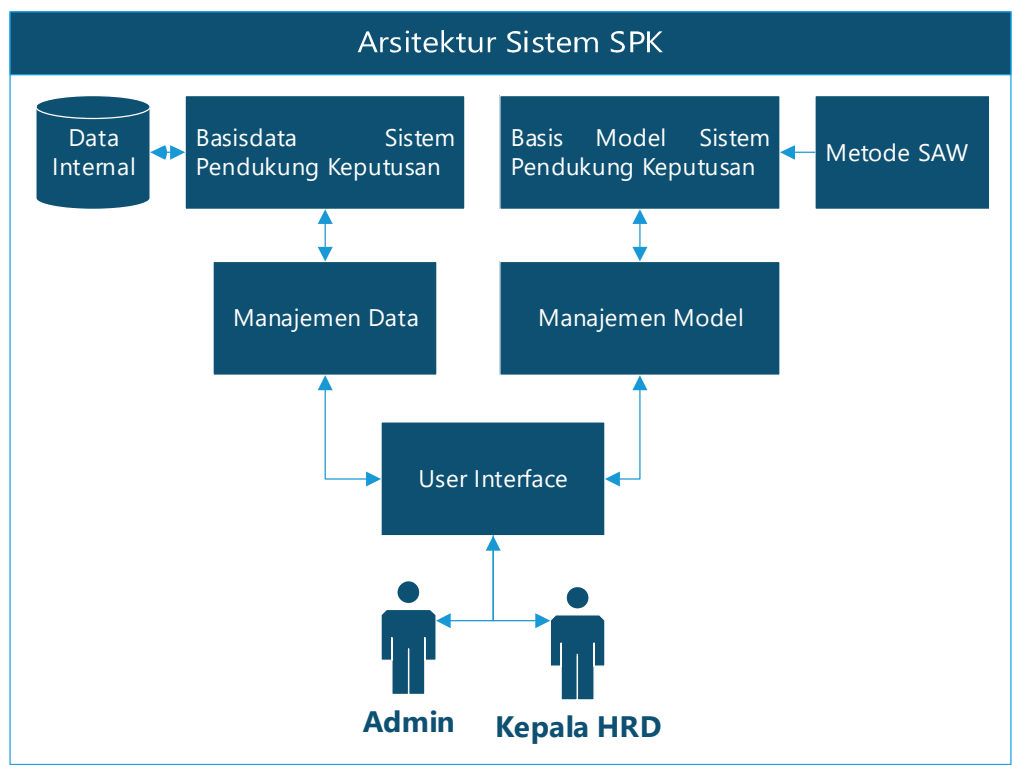

Gambar 1. Arsitektur Sistem

\section{6 Use case}

Use case merupakan suatu proses akses dan aktifitas aktor atau pengguna sistem. Pengguna aplikasi terdiri dari 2 pengguna yaitu administrator dan Kepala HRD. Untuk mengakses aplikasi setiap pengguna melakukan login terlebih dahulu. Administrator dapat melakukan manajemen data kriteria, manajemen data sub kriteria dan manajemen data alternatif/ calon penerima beasiswa bagi dosen studi lanjut di lingkungan STMIK Balikpapan. Sedangkan Kepala HRD dapat melakukan proses analisa tingkat kepentingan nilai setiap kriteria dan sub kriteria, dan analisa nilai preferensi setiap alternatif berdasarkan sub kriteria. Use case diagram sistem dapat dilihat pada Gambar 2.

JSIKTI Vol. 2, No. 3, June 2020 : $31-40$ 


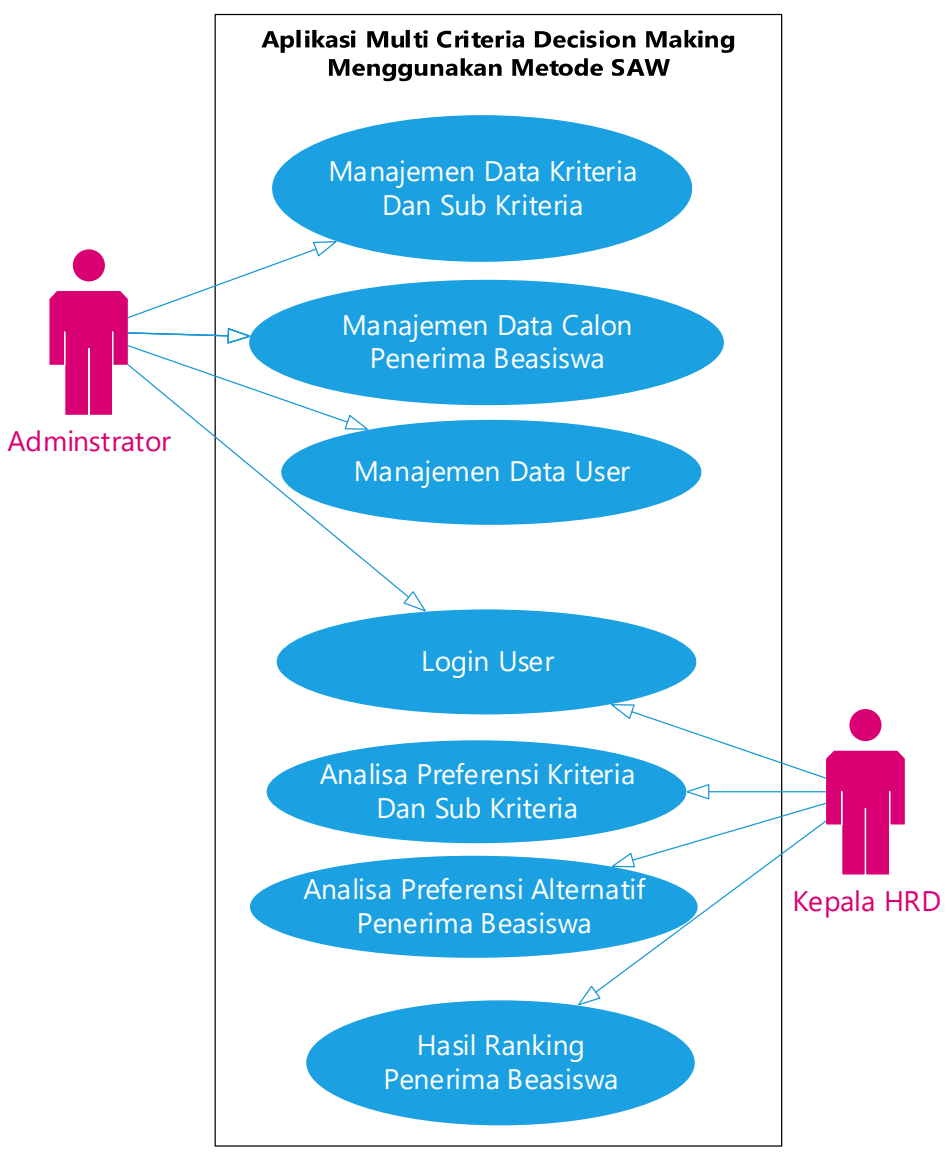

Gambar 2. Use Case Diagram

\section{HASIL DAN PEMBAHASAN}

Hasil dan pembahasan aplikasi MCDM terdapat beberapa tahapan, yang meliputi:

1. Evaluasi kriteria

Nilai preferensi kepentingan antar kriteria dan sub kriteria dapat dilihat pada tabel 1.

Tabel 1. Nilai Kepentingan antar kriteria dan sub kriteria

\begin{tabular}{|c|c|c|c|c|c|}
\hline No & Kriteria & $\begin{array}{c}\text { Nilai } \\
\text { Kriteria }\end{array}$ & Sub Kriteria & Nilai Sub Kriteria & Bobot Global \\
\hline \multirow[t]{3}{*}{1.} & \multirow{3}{*}{ Pengajaran } & \multirow{3}{*}{0,25} & Pedagogik & 0,35 & 0,09 \\
\hline & & & Kepribadian & 0,35 & 0,09 \\
\hline & & & Proposional & 0,30 & 0,08 \\
\hline \multirow[t]{3}{*}{2.} & \multirow[t]{3}{*}{ Penelitian } & \multirow[t]{3}{*}{0,30} & Penelitian Internasional & 0,40 & 0,12 \\
\hline & & & Penelitian Nasional & 0,30 & 0,09 \\
\hline & & & Jurnal Dan Prosiding & 0,30 & 0,09 \\
\hline \multirow[t]{3}{*}{3.} & \multirow[t]{3}{*}{ Pengabdian } & \multirow[t]{3}{*}{0,20} & Keaktifan pengabdian & 0,35 & 0,07 \\
\hline & & & Banyaknya Pengabdian & 0,35 & 0,07 \\
\hline & & & $\begin{array}{ll}\text { Ketepatan } & \text { Waktu } \\
\text { pengabdian } & \end{array}$ & 0,30 & 0,06 \\
\hline \multirow[t]{3}{*}{4} & \multirow[t]{3}{*}{ Pendidikan } & \multirow[t]{3}{*}{0,25} & IPK & 0,30 & 0,08 \\
\hline & & & Lineritas Program Studi & 0,40 & 0,10 \\
\hline & & & Riwayat Pendidikan & 0,30 & 0,08 \\
\hline
\end{tabular}


Nilai bobot global merupakan hasil perkalian antara nilai inputan kriteria dengan nilai sub kriteria masing masing. Misalnya: kriteria pengajaran (0.25) x nilai sub kriteria pedagogik $(0,35)$ menghasilkan nilai bobot global $=0,09$.

2. Evaluasi alternatif

Evaluasi alternatif merupakan nilai preferensi alternatif (calon penerima beasiswa) berdasarkan sub kriteria. Berdasarkan nilai preferensi tersebut di lakukan proses normalisasi matriks dan evaluasi karakteristik sub kriteria yaitu kategori benefit atau cost. Implementasi nilai preferensi setiap alternatif dapat dilihat Tabel 2.

Tabel 2. Nilai Preferensi Alternatif

\begin{tabular}{|l|c|c|c|c|c|c|}
\hline \multirow{2}{*}{ Alternatif } & \multicolumn{7}{|c|}{ Sub Kriteria Penilaian } \\
\cline { 2 - 7 } & SK1 & SK2 & SK3 & SK4 & SK5 & SK6 \\
\hline Wahyu Nur Alimningtias, S.Kom & 80 & 80 & 75 & 20 & 20 & 40 \\
\hline Tri Sudinugraha, S.Kom & 85 & 85 & 80 & 20 & 40 & 40 \\
\hline Heruzulkifli Rowa, S.Kom & 75 & 80 & 80 & 20 & 20 & 40 \\
\hline Ganang Bakti Arumbinang, S.Kom & 75 & 80 & 75 & 20 & 20 & 20 \\
\hline Yamani, S.S & 80 & 75 & 80 & 20 & 20 & 40 \\
\hline
\end{tabular}

Tabel 2. Nilai Preferensi Alternatif(Lanjutan)

\begin{tabular}{|l|c|c|c|c|c|c|}
\hline \multirow{2}{*}{ Alternatif } & \multicolumn{6}{c|}{ Sub Kriteria } \\
\cline { 2 - 7 } & SK7 & SK8 & SK9 & SK10 & SK11 & SK12 \\
\hline Wahyu Nur Alimningtias, S.Kom & 70 & 80 & 80 & 100 & 100 & 100 \\
\hline Tri Sudinugraha, S.Kom & 100 & 80 & 80 & 100 & 100 & 100 \\
\hline Heruzulkifli Rowa, S.Kom & 30 & 20 & 20 & 100 & 100 & 100 \\
\hline Ganang Bakti Arumbinang, S.Kom & 30 & 20 & 20 & 100 & 100 & 100 \\
\hline Yamani, S.S & 70 & 40 & 40 & 100 & 50 & 100 \\
\hline
\end{tabular}

Berdasarkan karakteristik sub kriteria semua parameter yang digunakan bersifat benefit maka di hitung proses nilai max. Benefit merupakan parameter nilai preferensi tinggi lebih baik. Nilai max untuk unsur sub kriteria pedagogik terhadap semua data alternatif yang dinilai inputan data $\max (80,85,75,75,80)=85$, maka dihasilkan nilai:
1) Wahyu Nur Alimningtias, S.Kom
$=80 / 85=0,941$
2) Tri Sudinugraha, S.Kom
$=85 / 85=1$
3) Heruzulkifli Rowa, S.Kom
$=75 / 85=0,882$
4) Ganang Bakti Arumbinang,S.Kom
$=75 / 85=0,882$
5) Yamani, S.S
$=70 / 85=0,941$

Tahapan spesifik perkalian bobot global dengan nilai normalisasi untuk setiap altenatif calon penerima beaiswa untuk dosen studi lanjut, yaitu:

1.) Wahyu Nur Alimningtias, S. Kom $=(0,09 * 0,941)+(0,09 * 0,941)+$ $(0,08 * 0,938)+(0,12 * 1)+(0,09 * 0,500)+(0,09 * 1)+(0,07 * 0,700)+(0,07 * 1)+(0,06 * 1)+$ $(0,08 * 1)+(0,10 * 1)+(0,08 * 1)=\mathbf{0 , 9 1 9}$

2.) Tri Sudinugraha, S.Kom $=(0,09 * 1)+(0,09 * 1)+(0,08 * 1)+(0,12 * 1)+(0,09 * 1)+(0,09 * 1)+$ $(0,07 * 1)+(0,07 * 1)+(0,06 * 1)+(0,08 * 1)+(0,10 * 1)+(0,08 * 1)=\mathbf{1}$

3.) Heruzulkifli Rowa, S.Kom $=0,09 * 0,882)+(0,09 * 0,941)+(0,08 * 1)+$ $(0,12 * 1)+(0,09 * 0,500)+(0,09 * 1)+(0,07 * 0,300)+(0,07 * 0,250)+(0,06 * 0,25)+(0,08 * 1)+(0,1$ $0 * 1)+(0,08 * 1)=\mathbf{0 , 7 9 3}$

4.) Ganang Bakti Arimbinang, S.Kom $=0,09 * 0,882)+(0,09 * 0,941)+(0,08 * 0,938)+$ $(0,12 * 1)+(0,09 * 0,500)+(0,09 * 0,500)+(0,07 * 0,300)+(0,07 * 0,250)+(0,06 * 0,25)+$ $(0,08 * 1)+(0,10 * 1)+(0,08 * 1)=\mathbf{0 , 7 4 3}$

5.) Yamani, S.S $=(0,09 * 0,941)+(0,09 * 0,882)+(0,08 * 1)+(0,12 * 1)+(0,09 * 0,500)+(0,09 * 1)+$ 


$$
(0,07 * 0,700)+(0,07 * 0,500)+(0,06 * 0,5)+(0,08 * 1)+(0,10 * 0,5)+(0,08 * 1)=\mathbf{0 , 8 0 4}
$$

3. Hasil ranking

Hasil akhir dalam penelitian ini adalah hasil ranking individu setiap calon penerima beasiswa untuk dosen studi lanjut dilingkungan STMIK Balikpapan. Hasil ranking berdasarkan nilai vektor dan bobot tertinggi dapat dilihat pada Gambar 3 .

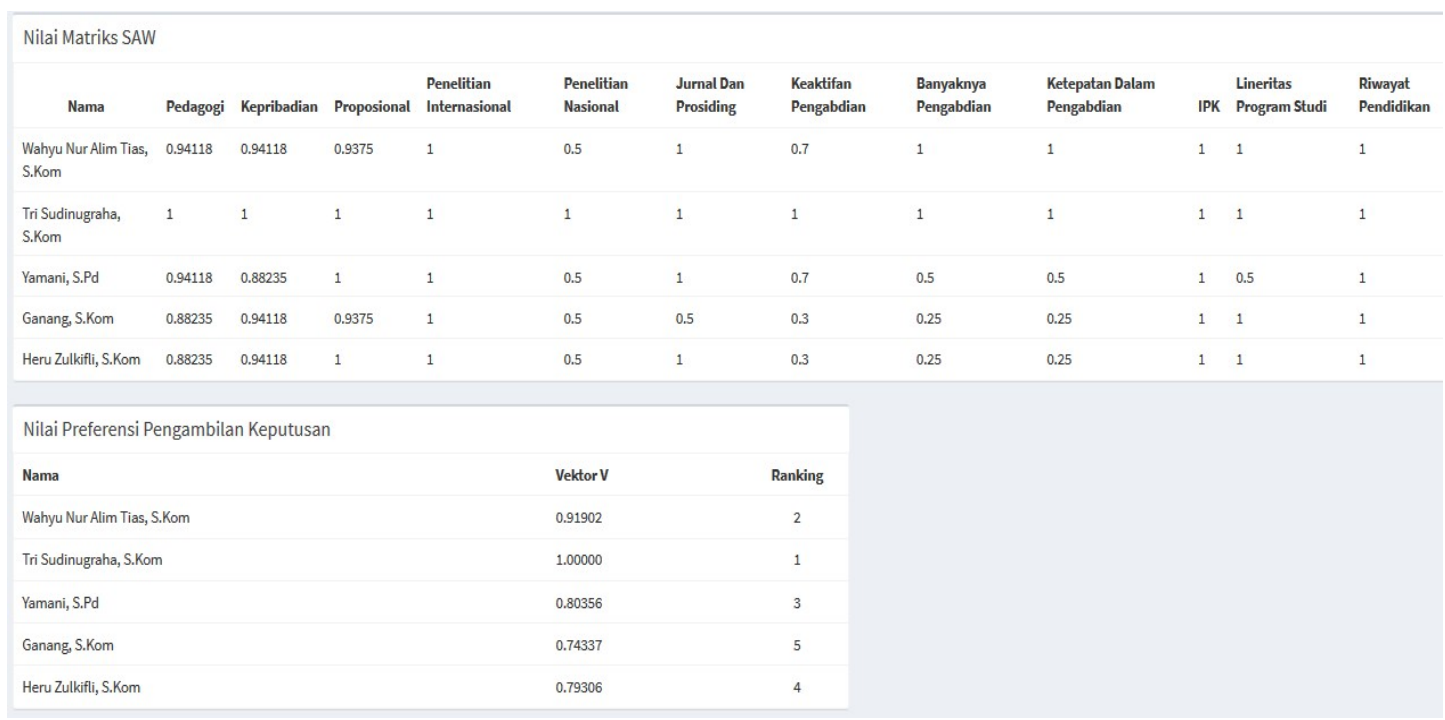

Gambar 3. Form Hasil Ranking MCDM

Hasil proses pemodelan multi criteri decision making(MCDM) menggunakan metode SAW menghasilkan urutan ranking dengan dari nilai bobot tertinggi yang meliputi: Tri Sudinugraha, S.Kom(1), Wahyu Nur AlimningTias, S.Kom(0,919), Yamani, S.S(0,804), Heruzulkifli Rowa, S.Kom(0,793), Ganang Bakti Arimbinang, S.Kom(0,743). Berdasarkan hasil bobot yang diperoleh maka urutan ranking dan proritas calon penerima beasiswa dosen untuk studi lanjut pada STMIK Balikpapan Adalah:

1.) Tri Sudinugraha, S.Kom

2.) Wahyu Nur Alimningtias, S.Kom

3.) Yamani, S.S

4.) Heruzulkifli Rowa, S.Kom

5.) Ganang Bakti Arimbinang, S.Kom

\section{KESIMPULAN}

Berdasarkan hasil evaluasi dan nilai preferensi decision maker dan proses pemodelan dalam aplikasi, maka dapat di simpulkan bahwa aplikasi multi criteria decision making(MCDM) menggunakan metode SAW dapat di jadikan sebagai bahan pertimbangan dan rekomendasi bagi Kepala HRD, Pimpinan di lingkungan STMIK Balikpapan dan Yayasan Airlangga dalam penentuan calon penerima beasiswa untuk dosen studi lanjut pada jenjang lebih tinggi dengan tingkat akurasi yang maksimal.

\section{SARAN}

Saran dan masukan untuk pengembangan penelitian selanjutnya agar menghasilkan nilai akurasi yang maksimal maka dapat dilakukan proses hybrid metode, misalnya $A H P$ dengan $S A W$, Atau Metode $A N P$ dengan $S A W$. Serta menerapkan perbandingan pemodelan multi criteria decision making, misalnya membandingan proses metode $S A W$, Weighted Product dan Topsis. 


\section{UCAPAN TERIMA KASIH}

Penulis memanjatkan Puji dan Syukur kehadirat Allah S.W.T atas limpahan rahmad dan hidayah-Nya sehingga dapat menyelesaikan penelitian ini. Penulis mengucapkan terima kasih kepada semua pihak atas dukungannya.

\section{DAFTAR PUSTAKA}

[1] Ye, H. J., Zhan, D. C., Li, X., Huang, Z. C., and Jiang, Y., 2017, College student scholarships and subsidies granting: A multi-modal multi-label approach. Proceedings IEEE International Conference on Data Mining, ICDM, 559-568. https://doi.org/10.1109/ICDM.2016.97

[2] Wei, W., Han, J., Kong, J., and Xia, H., 2017, Prediction of the Scholarship Using Comprehensive Development. Proceedings - 4th International Conference on Enterprise Systems: Advances in Enterprise Systems, ES 2016, 183-188. https://doi.org/10.1109/ES.2016.30

[3] Tsai, J.-P., Cheng, H.-Y., Wang, S.-Y., and Kao, Y.-C., 2010, Multi-criteria decision making method for selection of machine tool. 2010 International Symposium on Computer, Communication, Control and Automation (3CA), 49-52. https://doi.org/10.1109/3CA.2010.5533376

[4] Chaising, S., 2017, Application of a Hybrid Multi-Criteria Decision Making Approach for Selecting of Raw Material Supplier for Small and Medium Enterprises.

[5] Zhang, L., Xu, Y., Yeh, C., He, L., and Zhou, D., 2016, Bi-TOPSIS: A New Multicriteria Decision Making Method for Interrelated Criteria With Bipolar Measurement, 1-12.

[6] Kittur, J., 2015, Criteria Decision Making Methods.

[7] Rezaei, A., Shayestehfar, M., Hassani, H., and Mohammadi, M. R. T., 2015, Assessment of the metals contamination and their grading by SAW method: a case study in Sarcheshmeh copper complex, Kerman, Iran. Environmental Earth Sciences, 74(4), 3191-3205. https://doi.org/10.1007/s12665-015-4356-0

[8] Turban, E., Aronson, J. E., and Leang, T.-F., 2005, Decision Support Systems And Intelligent Systems (Edisi 7).

[9] Roscher, K., Jiru, J., and Knorr, R., 2017, Low-delay forwarding with multiple candidates for VANETs using multi-criteria decision making. IEEE Vehicular Networking Conference, VNC. https://doi.org/10.1109/VNC.2016.7835961

[10] Kittur, J., 2015, Optimal generation evaluation using SAW, WP, AHP and PROMETHEE multi - Criteria decision making techniques. Proceedings of IEEE International Conference on Technological Advancements in Power and Energy, TAP Energy 2015, 304-309. https://doi.org/10.1109/TAPENERGY.2015.7229636

JSIKTI Vol. 2, No. 3, June 2020 : $31-40$ 